\title{
MISLEADING PRESENTATION OF HAEMOGLOBIN ELECTROPHORESIS DATA
}

\author{
Patrick Adu ${ }^{1}$, Nicodemus L. Simpong ${ }^{2}$, Kate Kontor ${ }^{3}$, and Richrd K.D Ephraim ${ }^{1}$ \\ Ghana Med J 2017; 51(1): 36-38～DOI: http://dx.doi.org/10.4314/gmj.v51i1.7
}

\begin{abstract}
${ }^{1}$ Department of Medical Laboratory Technology, School of Allied Health Sciences, University of Cape Coast, Ghana, ${ }^{2}$ Maternity Department, 37 Military Hospital, Accra, Ghana, ${ }^{3}$ Medical OPD, Cape Coast Teaching Hospital, Cape Coast, Ghana.
\end{abstract}

Corresponding author: Dr. Patrick Adu

E-mail: Patrick.adu@ucc.edu.gh

Conflict of interest: None declared

\section{SUMMARY}

Haemoglobinopathies are common in sub-Saharan Africa. As such haemoglobin electrophoresis are required to inform clinical decision making. However, haemoglobin electrophoresis is an assay that detects protein at either alkaline or acidic $\mathrm{pH}$. Such assays do not interrogate gene sequences but rather the product of a gene. As many posttranscriptional and post-translational modifications impact the final output of the gene (i.e. protein), presentation of such protein-based assay must accurately reflect the technique employed. It is grossly misleading and scientifically inaccurate to report cellulose acetate and/or citrate agar haemoglobin electrophoresis results as 'haemoglobin genotype'. We propose a new paradigm in which haemoglobin electrophoresis data would be presented as 'haemoglobin phenotype' at a specified $\mathrm{pH}$.

Funding: None declared

Keywords: Electrophoresis, haemoglobinopathies, haemoglobin, cellulose acetate electrophoresis, citrate agar electrophoresis

\section{INTRODUCTION}

Many scientific literature reporting on various haemoglobin $(\mathrm{Hb})$ electrophoresis assays present the results as "Hb genotype" as could be evidenced in some sampled publications. ${ }^{1-3}$ However, from the scientific viewpoint, this reportage is grossly misleading and must be corrected as it leads to lots of misunderstanding in clinical practice. As explained elsewhere and also illustrated in Figure 1, protein expression is a series of events: gene that encodes messenger RNA production; mRNA splicing; protein synthesis; post-translational modification of protein and protein folding into native/functional molecule. ${ }^{4}$ Techniques that probe any aspect of this protein expression process must report its findings to reflect exactly what was measured to inform appropriate interpretation and clinical utility.

\section{Haemoglobin electrophoresis}

$\mathrm{Hb}$ electrophoresis is a technique that detects the presence of native protein and is thus far removed from the gene that encoded its synthesis. Although the technique is very useful, there is need for clarity as to what exactly the technique measures and what it does not.
This would help in defining the appropriate terminologies/nomenclature that is consistent with the electrophoretic technique and curtail any propensity to over-stretch the interpretation of its results beyond its intended use. Haemoglobin is composed of two molecules: haem and globin. The genes coding for globin chain synthesis are inherited on chromosome 11 ( $\beta$-gene cluster) and chromosome 16 ( $\alpha$-gene cluster). ${ }^{5-6}$

Inadequate or lack of globin chain synthesis (i.e. thalassaemias), and/or mutations that leads to production of abnormal structural globin chain synthesis (e.g. Hb S, C, $\mathrm{D}$ variants) collectively leads to the clinical conditions referred to as haemoglobinopathies. ${ }^{6}$ Within limits, $\mathrm{Hb}$ electrophoresis technique is a protein assay able to detect the presence of abnormal structural globin variants such as $\mathrm{Hb} \mathrm{S,} \mathrm{C,} \mathrm{D,} \mathrm{as} \mathrm{well} \mathrm{as} \mathrm{normal} \mathrm{variants} \mathrm{like} \mathrm{Hb} \mathrm{F}$ and $\mathrm{Hb} \mathrm{A} 2{ }^{5}$

However, the technique is generally silent on the thalassaemias. Taken together, in an individual co-inheriting an abnormal structural globin chain and defective globin chain synthesis defect. 
For example, $\mathrm{HbS} / \alpha$-thalassaemia, $\mathrm{HbC} / \beta$-thalassaemia, haemoglobin electrophoresis would estimate the $\mathrm{S}$ and $\mathrm{C}$ respectively but not directly on the $\alpha$ - and $\beta$ thalassaemias. Thus, such results could at best be presented as "Hb phenotype" to accurately reflect that the assay measured a protein. Only assays that employ polymerase chain reaction (PCR) or various gene sequencing platforms that interrogate the genes expressed on chromosomes should present such data as genotypes as these accurately deals with gene level assay (see Figure 1).

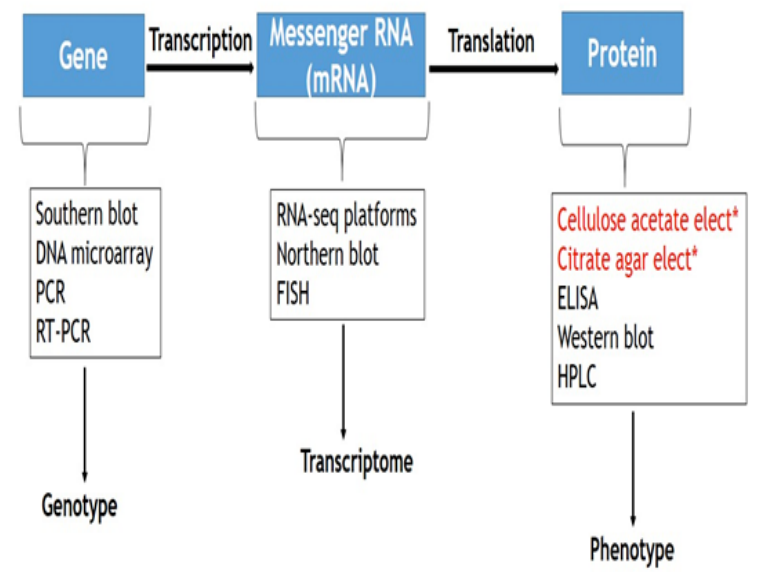

Figure 1 Schematic presentation of gene expression from mRNA to protein synthesis. Genes encode for mRNA production in the nucleus (transcription). Protein synthesis occurs on ribosomes in the cytoplasm (translation). Various techniques that may be used to assess each step of gene expression are listed under each stage with the subsequent outputs. $\mathrm{PCR}=$ polymerase chain reaction, $\mathrm{RT}-\mathrm{PCR}=$ reverse transcriptase $\mathrm{PCR}, \mathrm{FISH}=$ fluorescence in situ hybridization, ELISA= enzymelinked immunosorbent assay, HPLC $=$ high performance liquid chromatography.

\section{DISCUSSION}

In spite of the obvious limitations inherent in the $\mathrm{Hb}$ electrophoresis assay, some authors choose to report their data as "Hb genotype". For example, in alkaline/cellulose acetate electrophoresis ( $\mathrm{pH} 8.2$ - 8.6) (5, 7):

1. Haemoglobins $\mathrm{A}_{2}, \mathrm{C}, \mathrm{E}$ and $\mathrm{O}$ co-migrate to the same spot.

2. Haemoglobins S, D and G co-migrate to the same spot.

Thus, as illustrated in figure 2, the detection of haemoglobin bands at the $\mathrm{Hb} \mathrm{A}_{2}$ and $\mathrm{S}$ regions (after a cellulose acetate paper electrophoresis) does not necessarily mean the sample has only $\mathrm{Hb} \mathrm{A}_{2}$ and $\mathrm{S}$; such individual could as well have $\mathrm{Hb} \mathrm{S}$ and $\mathrm{C}$, or $\mathrm{Hb} \mathrm{D}$ and $\mathrm{C}$.
Additionally, the presence of only a single band in the S region (after cellulose acetate paper electrophoresis) also does not necessarily indicate that the individual is 'Hb SS genotype' (see Figure 1A).

Additionally, the $\mathrm{Hb}$ electrophoresis assay does not generally predict inheritance of thalassaemia. As shown in Figure 2B, employing both cellulose acetate and citrate agar electrophoresis in analyzing the same sample has the advantage of a greater coverage. However, this is not the case in clinical practice in our hospital settings; even in cases where both techniques are employed, they still deal with proteins.

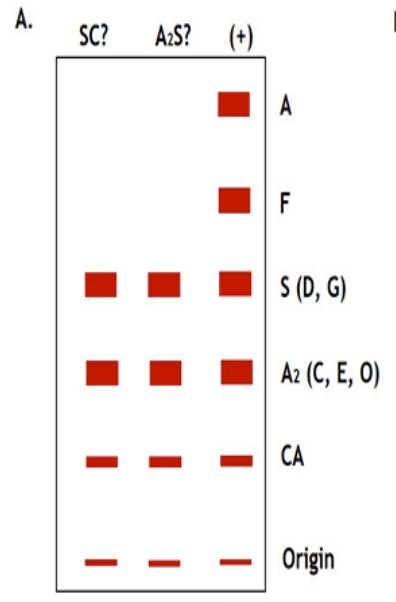

$(-)$

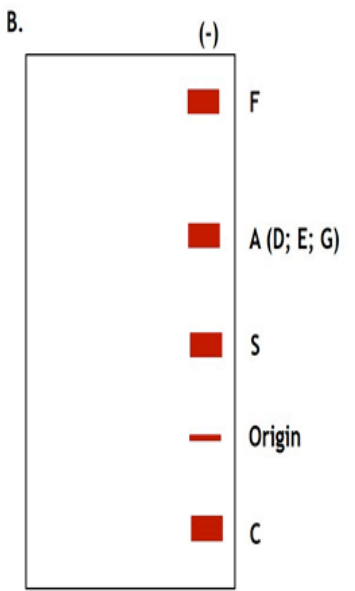

$(+)$
Figure 2 A typical electrophoretic mobility pattern at two separate pHs. Figure A is a cellulose acetate electrophoresis read-out; note that haemoglobins $\mathrm{A}_{2}, \mathrm{C}, \mathrm{E}$ and $\mathrm{O}$ co-migrate whereas haemoglobins $\mathrm{S}, \mathrm{D}$, and $\mathrm{G}$ also co-migrate at alkaline $\mathrm{pH}$. Figure $\mathrm{B}$ is a citrate agar electrophoresis plate $(\mathrm{pH}=6.0)$; note that haemoglobins $\mathrm{A}, \mathrm{D}, \mathrm{E}$ and $\mathrm{G}$ co-migrate at this $\mathrm{pH}$.

Moreover, many issues of disputed parentage arise in cases where the implicated child might have inherited a compound defect comprising a globin chain synthesis defect (e.g. thalassaemia intermedia) and a structural haemoglobin defect (e.g. Hb S or C). Ensuring that the $\mathrm{Hb}$ electrophoresis assay data is accurately presented becomes crucial in such instances as spousal integrity and/or parental responsibilities would be at stake.

Thus, the scientific community owes the public the debt of ensuring that data presented in the literature and/or laboratory report form is a reflection of the strengths as well as the limitations of the technique employed to remove all causes of misunderstanding in the public domain. This is not only ethically required but a moral responsibility as well. 
Evidently, the various gene assay platforms (see figure 1) offers lots of leverage with regards to understanding the pathophysiology of disease processes. These are able to determine the exact mutation, and/or chromosomal aberrations that may underlie a particular disease process. ${ }^{8}$ It is also able to detect single nucleotide polymorphisms (SNPs) that may modulate the pathology of certain diseases as well as differences in responses to the same drug therapy. ${ }^{9}$

As these advanced techniques are being used to map diseases and subsequently tailor treatment to the exact needs of individual patients elsewhere ${ }^{10}$, developing countries should do well to invest capital in these technologies so as to tap into the enormous potential of these state of the art technologies.

\section{CONCLUSION}

Presentation of any data as 'genotype' must be reserved for data emanating from such platforms as PCR or DNA microarray. We propose a new paradigm in which haemoglobin electrophoresis data would be presented as 'haemoglobin phenotype' at a specified $\mathrm{pH}$.

\section{REFERENCES}

1. C.T. O, Esan AJ, ., Ogunleye AA, Ojo-Bola O, Owoseni MF, Omoniyi DP. Glucose-6-Phosphate Dehydrogenase (G6PD) Deficiency and Sickle Cell Trait among Blood Donors in Nigeria. American Journal of Public Health Research 2014;2(2):51-5.

2. Samuel Antwi-Baffour ROA, Jonathan Kofi Adjei, Ransford Kyeremeh and David Nana Adjei Prevalence of hemoglobin S trait among blood donors: a cross-sectional study. BMC Research Notes. $2015 ; 8(583)$

3. Egesie O J EUG, Jatau E D, Isiguzoro I 1, Ntuhun D B. Prevalence of Sickle Cell Trait and Glucose 6 Phosphate Dehydrogenase Deficiency among Blood Donors in a Nigerian Tertiary Hospital. Afr J Biomed Res 2013;16:143 - 7.

4. Lodish Harvey BA, Kaiser A. Chris, Kreiger Monty, Scott P. Mathew, Bretscher Anthony, Ploegh Hidde, Matsudaira Paul. Molecular Cell Biology. Sixth ed. New York: W.H. Freeman and Company; 2008.

5. Barabara J. Bain IB, Michael A Laffan, S. Mitchell Lewis. Dacie and Lewis Practical Haematology: Elsevier Churchill Livingstone; 2011. 650 p.

6. Hoffbrand AV, Moss, P.A.H. Essential haematology. 6th ed. UK: Blackwell Publishing Ltd; 2011.

7. Assendelft OWv. Detection and identification of haemoglobin variants In: Rowan R. Martin PFE, Onno W. van Assendelft editor. Advanced Laboratory Methods in Haematology Oxford, UK: Arnold Publishers; 2002. p. 195-206.

8. Green ED, Guyer MS, National Human Genome Research I. Charting a course for genomic medicine from base pairs to bedside. Nature. 2011;470(7333):204-13.

9. Gray IC, Campbell DA, Spurr NK. Single nucleotide polymorphisms as tools in human genetics Human molecular genetics 2000;9(16):2403-8.

10. Alkuraya FS. The application of next-generation sequencing in the autozygosity mapping of human recessive diseases Human genetics 2013;132(11):1197-211. 